\title{
Status of the flame chub Hemitremia flammea in Alabama, USA
}

\author{
Bruce Stallsmith* \\ Department of Biological Sciences, University of Alabama in Huntsville, Huntsville, Alabama 35899, USA
}

\begin{abstract}
The status of many freshwater fish species in the species-rich southeastern United States is surprisingly poorly known. Vulnerable species found in smaller streams in the region have not received adequate research attention. The flame chub Hemitremia flammea (Cyprinidae) is included among a group of stream species considered to be 'narrow endemics' susceptible to habitat alterations due to growing human population. The obligatory habitat is spring-fed streams sensitive to human activities. The species has a patchy range primarily in the Tennessee River Valley in Alabama and Tennessee, USA. The conservation status of the flame chub is poorly documented. The NatureServe global status of the flame chub is G3, Vulnerable, and the Alabama state status is S3, Vulnerable. Reflecting the poor knowledge of the species' status, the International Union for the Conservation of Nature (IUCN) Red List Category is DD (Data Deficient), a change from an earlier listing of Rare. This study is intended as a presence or absence survey of flame chubs at historic location sites in north Alabama based on holdings records of the University of Alabama Ichthyology Collection in Tuscaloosa, Alabama. Fifty-three sites in 9 counties in the Tennessee River drainage with a historic record of flame chub presence were visited and sampled by seining. One or more flame chubs were found at 18 of these sites. Two strongholds remain for the flame chub in Alabama: the first is much of the Cypress Creek system in Lauderdale County; the other is in the Flint River system in Madison County.
\end{abstract}

KEY WORDS: Flame chub $\cdot$ Hemitremia flammea $\cdot$ Narrow endemic $\cdot$ Population $\cdot$ Occurrences

\section{INTRODUCTION}

The status of many freshwater fish species in the species-rich southeastern United States is surprisingly poorly known (Warren et al. 2000, Butler 2002). States in the Tennessee River system draining the southern Appalachian Mountains have by far the highest freshwater fish diversity in North America, in particular Alabama and Tennessee, each with over 325 known species (Etnier \& Starnes 1993, Boschung et al. 2004). Attempts to characterize the status of some rare river species such as the snail darter Percina tanasi (Percidae) or the Alabama sturgeon Scaphirhyncus suttkusi (Acipenseridae) have sparked political controversy and drawn media attention even as exploratory field work is being conducted and information gathered
(Norman 1981, Mayden \& Kuhajda 1996). Both of these species have suffered from the alteration of river habitat by dam construction.

Vulnerable fish species found in smaller streams in the same region have not received the same level of attention from either the popular media or government agencies. One example is the Alabama pygmy sunfish Elassoma alabamae (Elassomatidae), which was considered extinct for $35 \mathrm{yr}$ after several springs were drowned in 1938 by the dam-created Pickwick Pool on the Tennessee River until another isolated spring population was discovered (Boschung et al. 2004). Another example is the federally Threatened slackwater darter Etheostoma boschungi (Percidae), with populations now fragmented in 2 river systems as more and more habitat is lost to changing land 
use (McGregor \& Shepard 1995, Boschung et al. 2004).

The flame chub Hemitremia flammea Jordan and Gilbert, 1878 (Cyprinidae), is another regional species considered to be in decline. It is included among a group of stream species described as 'narrow endemics' that are susceptible to habitat alterations due to growing human population; spring habitat fishes are especially in jeopardy (Warren et al. 2000, Butler 2002). The obligatory habitat is spring-fed streams sensitive to human activities. Currently the species has a patchy range, primarily in the Tennessee River Valley from the mouth of the Duck River in Tennessee upstream through Alabama to the Knoxville, Tennessee, area. Most of the Alabama portion of this range is within the Highland Rim or Cumberland Plateau physiographic sections (Mettee et al. 1996). One isolated population is known from north Georgia in the Tiger Creek watershed of Catoosa County (Freeman et al. 2009). Kentucky populations are considered by the Commonwealth of Kentucky to have been extirpated, although putative vouchers of Kentucky flame chubs are either missing or are now known to have been misidentified (Kentucky State Nature Preserves Commission 2004, B. Burr pers. comm.). Disjunct flame chub populations in Alabama's Calhoun and Talladega Counties in the Mobile Basin of the Alabama Valley and Ridge physiographic section to the south of the Tennessee Valley are considered to be extirpated (Boschung et al. 2004).

The conservation status of the flame chub is poorly documented. According to NatureServe (2009), the global status of the flame chub is G3, Vulnerable, and the Alabama state status is S3, Vulnerable. Reflecting the poor knowledge of the species' status, the International Union for the Conservation of Nature (IUCN) Red List Category is DD (Data Deficient), a change from earlier listings of Rare (Gimenez-Dixon 1996). Virtually all of the spring-fed stream habitat needed by flame chubs is on private land, further complicating assessments of the species' status. Prior to the current study, the only known population in a protected area was in Cades Cove, Tennessee, within the Great Smoky National Park managed by the US National Park Service.

The current study is intended as a presence or absence survey of flame chubs at historic location sites in north Alabama. The Alabama section is approximately $50 \%$ of the remaining range and is compact enough for thorough sampling to be carried out in a reasonable time period. Land use changes including both increased cropland density and the conversion of agricultural lands to housing are accelerating in this area, centered on the expansion of the city of Huntsville. Such land use changes are widespread in the southeastern United States and are affecting freshwater communities across the region (Powell 2003, Scott 2006). By sampling a large number of these historic sites across the northern tier of Alabama, it should be possible to construct an accurate snapshot of the species' status. The viability of population occurrences was assessed using the Generic Element Occurrences Approach available through the NatureServe website (www.natureserve.org; Tomaino et al. 2008).

\section{MATERIALS AND METHODS}

A representative selection of streams in the Tennessee River basin in north Alabama was sampled to determine the current distribution of the flame chub. The decision as to which sites were to be sampled ('historic collection sites') was based primarily on museum holdings of the University of Alabama Ichthyology Collection (UAIC). A spreadsheet of 151 museum holdings of flame chubs from Alabama dating back to 1965 was provided by the curator of the UAIC. The list contains the latitude and longitude of collection sites as well as date of collection, how many individual fish were deposited in the UAIC, and observations on the stream and immediate environment. Because of multiple holdings from some sites, the 151 holdings represent approximately 80 unique flame chub collection sites. Data collected by the governmental Tennessee Valley Authority from an Index of Biotic Integrity project were also used to determine 2 more historic sites for sampling. These sites represent 9 north Alabama counties: Blount, Franklin, Jackson, Lauderdale, Lawrence, Limestone, Madison, Marshall, and Morgan. Also in the UAIC's 151 holdings are collections from disjunct populations believed to be extirpated in Calhoun and Talladega Counties in the Coosa River drainage to the southeast of the Tennessee drainage, part of the Mobile Basin. One of these sites in Calhoun County was also sampled.

The underlying geology for most of these streams is limestone karst, which is conducive to the formation of springs. Streams are typically fed by many small springs along their length. Such an undisturbed stream supporting flame chubs would have clear, flowing water over sand or gravel substrate with a $\mathrm{pH}$ of $7-8$ and moderate total dissolved solids (TDS) of about $100 \mathrm{ppm}$. North Alabama has a mild temperate climate with rare extended winter freezes. Annual rainfall averages $125 \mathrm{~cm}$ (Mettee et al. 1996).

Water temperature, $\mathrm{pH}$, and TDS (measured as ppm) were measured and recorded for each site as indicators of environmental quality. A water sample to be tested was collected in a small bucket before seining, and measurements were taken from this bucket in the 
shade. Temperature was measured with an alcohol thermometer, TDS was measured with a Hanna Instruments TDS 1 model TDS meter, and pH was measured with a Hanna Instruments pHep 2 model $\mathrm{pH}$ meter.

Stream sampling for flame chubs. Fifty-three sites with a historic record of flame chub presence were visited and sampled by seining between May 2005 and October 2007. Sites were selected from across the range defined by historic records. Some sites were on private land and unavailable for sampling, including several sites behind barbed wire which are currently used for cattle pasture. Sampling at each site was done with a $3 \times 1.3 \mathrm{~m}$ seine net with a mesh size of $3 \times 3 \mathrm{~mm}$. Most sites were small streams or spring runs, rarely more than $5 \mathrm{~m}$ wide or deeper than $1 \mathrm{~m}$, generally accessible at a road bridge crossing a stream. Flame chubs are most commonly found in shallow, slow-moving stream pools especially in association with aquatic vegetation, so such areas were preferentially sampled. If possible and appropriate, a $200 \mathrm{~m}$ stream stretch was sampled through 'kick-netting' at 5 to $10 \mathrm{~m}$ intervals, with 1 or more people kicking downstream to chase fish into the net held in a fixed position. Other sites such as spring pools or small spring runs were sampled by sweeping with the seine net. Because the primary goal of this survey was to determine presence or absence of flame chubs, sampling would generally end soon after any flame chubs were found. Voucher specimens of 1 to 5 individuals were kept from each site that yielded flame chubs, preserved in $95 \%$ ethanol, and placed in the author's ichthyology collection currently in the Department of Biological Sciences at the University of Alabama in Huntsville, Alabama, USA.

For sites where at least 1 flame chub was found, the relative abundance of flame chubs was rated as 'common,' 'uncommon,' or 'single fish.' 'Common' indicates that 5 or more flame chubs were captured, usually quickly. 'Uncommon' indicates that 2 to 4 flame chubs were captured during repeated seining efforts. 'Single fish' sites were those in which a single flame chub was captured in as many as several dozen seining efforts over as long as $2 \mathrm{~h}$.

Occurrence ranking key. Estimated viability ranks were assigned to each visited site using the methods developed for NatureServe member programs (Hammerson et al. 2008, Tomaino et al. 2008). This is intended to make a concise assessment of the probability of persistence of a species for the foreseeable future, generally at least 20 to $30 \mathrm{yr}$. The use of these assessments in this study was based on how many flame chubs were caught, the condition of the stream, the condition of the riparian area along the stream, and apparent land use trends nearby, such as expanding housing developments or road enlargement that could reasonably be assumed to degrade stream quality in the near future.
The rankings and what they imply about a site and its population are as follows, based on Tomaino et al. (2008):

(A) Excellent viability: The population is very likely to last for the next 20 to $30 \mathrm{yr}$. The population appears to be large, and the size, condition, and quantity of the habitat are optimal.

(B) Good viability: The population size is likely to last for the next 20 to $30 \mathrm{yr}$ in similar or better condition. Some aspects of size, condition, and quantity of the habitat are favorable.

(C) Fair viability: There is some uncertainty about the long-term persistence of the population. Few aspects of the size, condition, and quantity of the habitat are favorable.

(D) Poor viability: If current conditions persist, there is a high probability of extirpation. This high probability is the result of small population size, degraded habitat, or inappropriate management that is unlikely to change.

(F) Failed to find: Recent surveys have failed to locate a population. Additional surveys are needed for sufficient evidence that the population has been extirpated.

(X) Extirpated: Persuasive evidence has been found that the species no longer occurs at this site.

These ranks can be blended, i.e. AB is excellent to good viability and CD is fair to poor viability.

\section{RESULTS}

\section{Water chemistry measurements}

Water temperature of sampled streams ranged from $8^{\circ} \mathrm{C}$ in February to $24^{\circ} \mathrm{C}$ in July, $\mathrm{pH}$ values ranged from 6.4 to 8.2 , and TDS varied from 17 to $213 \mathrm{ppm}$. The average TDS was $102 \mathrm{ppm}$ for sites where no flame chubs were found, and $89 \mathrm{ppm}$ for sites where flame chubs were found. A 2-tailed $t$-test of the 2 data sets showed no significant difference between sites with and without flame chubs $(\mathrm{p}=0.43)$.

\section{Flame chub presence/absence}

Flame chubs were found at 18 of the 53 sites sampled (see the interactive map in the supplement at www.intres.com/articles/suppl/n012p087_supp/). Table 1 summarizes when a site was sampled, and gives the relative abundance of flame chubs if encountered, and an occurrence ranking. An occurrence ranking for each site is based on the number and ease of capture of flame chubs, and physical attributes of the stream and its environs. Of the 35 sites sampled where no flame 
Table 1. Historic collection sites visited in north Alabama, USA, to assess presence/absence of flame chub Hemitremia flammea. Occurrence rankings were as follows: A: excellent viability, B: good viability, C: fair viability, D: poor viability, F: failed to find, $\mathrm{X}$ : extirpated. Note that ranks could be combined (e.g. AB: excellent to good viability). For relative abundance, common: $>5$ fish found; uncommon: 2 to 4 fish found. C.R.: county road. See 'Materials and methods' for details of occurrence rankings and abundance estimates

\begin{tabular}{|c|c|c|c|c|}
\hline Site & $\begin{array}{l}\text { Last historic } \\
\text { collection }\end{array}$ & $\begin{array}{c}\text { Date } \\
\text { visited }\end{array}$ & $\begin{array}{l}\text { Occurrence } \\
\text { ranking }\end{array}$ & $\begin{array}{c}\text { Relative } \\
\text { abundance }\end{array}$ \\
\hline \multicolumn{5}{|l|}{ Calhoun County } \\
\hline Choccolocco Creek, Joseph Springs Motor Way & 2001 & October 2007 & $\mathrm{~F}$ & \\
\hline \multicolumn{5}{|l|}{ Franklin County } \\
\hline Cedar Creek, C.R. 63 & 2004 & October 2007 & $\mathrm{~F}$ & \\
\hline Robinson Creek, C.R. 61 & 2004 & October 2007 & $\mathrm{~F}$ & \\
\hline \multicolumn{5}{|l|}{ Jackson County } \\
\hline Blue Spring, C.R. 20 & 1966 & June 2005 & $\mathrm{~F}$ & \\
\hline Beason Spring, Highway 65 & 1966 & June 2005 & $\mathrm{~F}$ & \\
\hline Lick Fork of Paint Rock River, C.R. 3 & 2001 & June 2005 & $\mathrm{AB}$ & Common \\
\hline Larkin Fork of Paint Rock River, C.R. 27 & 2001 & June 2005 & $\mathrm{~F}$ & \\
\hline Larkin Fork of Paint Rock River, C.R. 27 & 1980 & June 2005 & $\mathrm{~F}$ & \\
\hline \multicolumn{5}{|l|}{ Lauderdale County } \\
\hline Dry Branch, C.R. 139 & 1974 & July 2006 & $A B$ & Common \\
\hline Olive Spring, near C.R. 139 & 1974 & July 2006 & A & Common \\
\hline Little Cypress Creek, C.R. 11 & 1976 & July 2006 & $\mathrm{AB}$ & Common \\
\hline Little Cypress Creek, C.R. 8 & 2002 & July 2006 & $\mathrm{BC}$ & Uncommon \\
\hline King Spring, Mars Hill Rd. & 1993 & July 2006 & $\mathrm{AB}$ & Common \\
\hline Greenbrier Branch, C.R. 259 & 1974 & July 2006 & B & Common \\
\hline Cypress Creek, C.R. 8 & 1974 & July 2006 & $\mathrm{~F}$ & \\
\hline Lindsay Creek, C.R. 81 & 1974 & July 2006 & $\mathrm{~F}$ & \\
\hline Burcham Creek, C.R. 106 & 1974 & July 2006 & $\mathrm{~F}$ & \\
\hline Burcham Creek tributary, C.R. 106 & 1976 & July 2006 & $\mathrm{~F}$ & \\
\hline Burcham Creek, C.R. 112 & 1974 & July 2006 & $\mathrm{~F}$ & \\
\hline Bruton Branch, end of C.R. 241 & 1976 & July 2006 & $\mathrm{X}$ & \\
\hline North Fork Cypress Creek, Natchez Trace Parkway & 1979 & July 2006 & $\mathrm{~B}$ & Common \\
\hline \multicolumn{5}{|l|}{ Lawrence County } \\
\hline Gillespie Creek, C.R. 86 & 1971 & June 2006 & $\mathrm{~F}$ & \\
\hline Lee Creek, C.R. 86 & 1971 & June 2006 & $\mathrm{~F}$ & \\
\hline Mallard Creek, Highway 72 & 1980 & June 2006 & $\mathrm{~F}$ & \\
\hline Wheeler Branch, C.R. 388 & 1976 & June 2006 & $\mathrm{~F}$ & \\
\hline \multicolumn{5}{|l|}{ Limestone County } \\
\hline Moss Spring, Greenbrier Rd. & 1974 & February 2006 & $\mathrm{~F}$ & \\
\hline Piney Creek, Nick Davis Rd. & 1976 & February 2006 & $\mathrm{~F}$ & \\
\hline Johnson Branch, Copeland Rd. & 1982 & February 2006 & $\mathrm{~F}$ & \\
\hline Panther Branch, Copeland Rd. & 1982 & February 2006 & $\mathrm{C}$ & Single fish \\
\hline Swan Creek, Elkton Rd. & 1976 & April 2006 & $\mathrm{C}$ & Single fish \\
\hline Swan Creek, Piney Chapel Rd. & 1982 & April 2006 & $\mathrm{~F}$ & \\
\hline Little Round Creek, Highway 99 & 1975 & April 2006 & $\mathrm{X}$ & \\
\hline Little Piney Creek, Bethel Rd. & 1975 & April 2006 & $\mathrm{C}$ & Single fish \\
\hline Piney Creek, Wales Rd. & 1982 & April 2006 & $\mathrm{~F}$ & \\
\hline Spring Creek, Laughmiller Rd. & 1976 & May 2006 & $\mathrm{~F}$ & \\
\hline Mud Creek, Lindsay Rd. & 1976 & May 2006 & $\mathrm{C}$ & Single fish \\
\hline \multicolumn{5}{|l|}{ Madison County } \\
\hline Mountain Fork, Winchester Rd. & 2001 & May 2005 & B & Common \\
\hline \multirow{2}{*}{\multicolumn{5}{|c|}{ Buddy Williamson Rd. }} \\
\hline & & & & \\
\hline Tremble Creek, Old Highway 431 & 1976 & June 2005 & $\mathrm{~F}$ & \\
\hline Acuff Spring, Jordan Rd. & 1966 & June 2005 & $\mathrm{~B}$ & Common \\
\hline Blue Springs Run, Dug Hill Rd. & 1993 & June 2005 & $\mathrm{X}$ & \\
\hline Beaverdam Creek, off Baltimore Hill Rd. & 1976 & June 2005 & $\mathrm{~F}$ & \\
\hline Copeland Creek, Butter \& Egg Rd. & 1976 & June 2005 & $\mathrm{~F}$ & \\
\hline Dry Creek, Kelly Springs Rd. & 1976 & July 2005 & $\mathrm{~F}$ & \\
\hline Dry Creek, Highway 53 & 1976 & July 2005 & $\mathrm{~F}$ & \\
\hline Beaverdam Creek, Pulaski Pike & 1976 & July 2005 & $\mathrm{~F}$ & \\
\hline Brier Fork, Highway 231/431 & 1976 & July 2005 & $\mathrm{X}$ & \\
\hline Kelly Spring, Kelly Spring Rd. & 1966 & July 2005 & $\mathrm{CD}$ & Single fish \\
\hline Dry Creek, Old Monrovia Rd. & 1990 & July 2005 & $\mathrm{CD}$ & Uncommon \\
\hline \multicolumn{5}{|l|}{ Marshall County } \\
\hline Eudy Cave, Light Gap Rd. & 1993 & June 2006 & B & Common \\
\hline \multicolumn{5}{|l|}{ Morgan County } \\
\hline West Fork, Cotaco Creek, Childers Rd. & 1993 & June 2006 & $\mathrm{~F}$ & \\
\hline Crowdabout Creek, Andrews Rd. & 1976 & June 2006 & $\mathrm{~F}$ & \\
\hline Dutton Creek, South Danville Rd. & 1993 & June 2006 & $\mathrm{C}$ & Single fish \\
\hline
\end{tabular}


chubs were found, 31 were rated as $F$, and 4 were rated as $\mathrm{X}$. The $4 \mathrm{X}$ sites showed evidence of permanent alteration or destruction of a stream. The frequency of occurrence rankings for the 18 sites where flame chubs were found is as follows: $1 \mathrm{~A}, 4 \mathrm{AB}, 5 \mathrm{~B}, 1 \mathrm{BC}, 5 \mathrm{C}$, and 2 CD.

Lauderdale County was the only county where flame chubs were found at a slight majority of the sites visited, 7 of 13, and were common where found. Five of the sites with flame chubs were in the largely undisturbed Little Cypress Creek system. Several sites visited in Lauderdale County no longer seem to be regularly flowing creeks. Two sites in the Burcham Creek system were dry and showed evidence of having been so for some time in the drought conditions prevailing that year, with truck tire ruts and terrestrial weeds in the creek bed, but were ranked as F since they may contain water again. The site at Bruton Branch had been extensively reworked with construction equipment for housing construction, and the creek has disappeared, resulting in an element occurrence ranking of $\mathrm{X}$.

Two other counties make up most of the remaining sites found to contain flame chubs. Four of 11 sites visited in Limestone County and 4 of 13 sites visited in Madison County yielded flame chubs. All 4 of the Limestone County sites yielded only a single specimen, but flame chubs were common at 2 of the Madison County sites. Three sites in Limestone and Madison Counties appear to have been significantly altered since collections held by the UAIC were made, and therefore received an element occurrence of X. For instance, Little Round Creek at Highway 99 has been extensively excavated for road and drainage projects; Blue Springs Run at Dug Hill Road has lost most of the $2 \mathrm{~km}$ of its headwaters to suburban subdivision development, including the exact location of the historic collection, which is now a community center; and Dry Creek at Highway 53 seems to have filled in from siltation and is an intermittent stream.

Lauderdale, Limestone, and Madison Counties are all on the north side of the Tennessee River, and in sum flame chubs were found at 15 of 37 historic sites sampled. The fourth county north of the Tennessee River, Jackson, yielded flame chubs at only 1 of 5 sites visited. All 5 of these sites are in the Paint Rock River valley, well-known for its high fish diversity.

Ten historic collections sites were visited and sampled on the south side of the Tennessee River, in Franklin, Lawrence, Marshall, and Morgan Counties. Flame chubs were found at 2 of these sites. The only site where flame chubs were common was at Eudy Cave in Marshall County, in a tiny spring run on a dairy farm. Wheeler Spring in Lawrence County, the site of 3 historic collections since 1965, was visited but was impossible to sample because of high water created by a beaver dam across the spring pool's outlet. Gillespie Creek and Lee Creek, both on County Road 88 in Lawrence County, showed evidence of altered flow from a raised roadway being built through the area, and Wheeler Branch on County Road 388 has been channelized. Two sites in Franklin County, Cedar Creek at County Road 63 and Robinson Creek at County Road 61, yielded no flame chubs. Robinson Creek was a series of stagnant, intermittent pools as the result of drought. The single historic site in Blount County, Big Spring Creek, was visited but was impossible to sample due to difficult access because of dense undergrowth and deep water.

In the Coosa River drainage of the Mobile Basin, Choccolocco Creek at Joseph Springs Motor Way in Calhoun County was sampled in October 2007. Sampling along approximately $500 \mathrm{~m}$ of creek upstream of Joseph Springs Motor Way yielded no flame chubs. This is a historic site in which small numbers of flame chubs were collected in 1986 (currently part of the UAIC) and have been considered extirpated since. One group of researchers collected several flame chubs in this creek in 2002 while looking for other species (B. Kuhajda pers. comm.).

\section{DISCUSSION}

A species like the flame chub that is a 'narrow endemic' by definition has a patchy distribution naturally. This makes it more difficult to determine if such a species is in decline. The results of this survey show that the flame chub is in decline in Alabama, being found in 18 of 53 historic sites sampled. It is of course possible, perhaps likely, that flame chubs were present but missed at 1 or more sites. Even if this was true for 7 sites, that would still leave flame chubs missing from a full half of the sampled historic sites. Of the 18 sites where at least a single flame chub was found, 7 sites were assigned an element occurrence of $\mathrm{C}$ or $\mathrm{CD}$, with at best fair long-term population viability.

There is a strong geographical pattern to the remaining flame chub populations in Alabama. Two primary strongholds exist for this species in north Alabama. The first is the central and eastern parts of the Cypress Creek system in Lauderdale County in the Highland Rim physiographic section, where the 7 flame chub sites were all ranked with an element occurrence of BC or higher (Table 1). Burcham Creek and Bruton Branch in the western part of this system seem to have lost flame chubs as a result of human alterations of streams and stream flow. The other flame chub stronghold is in the Flint River system in Madison County in the Cumberland Plateau physio- 
graphic section, comprising Mountain Fork of the Flint River and Acuff Spring, both with an element occurrence rank of $B$ (Table 1). Flame chubs were easily seined in Mountain Fork just below a lowhead dam. Acuff Spring was the only sampled site where schools of flame chubs were easily observed. However, this site is under various stresses. The spring is on land that belongs to and is managed by a private housing development. Recently, the management has treated the spring run with herbicide to kill 'unsightly' native aquatic vegetation, and a friend of the developer has repeatedly released exotic koi into the spring run to 'improve' it (C. Cox pers. comm.).

King (Buffler) Spring, just outside the city of Florence in Lauderdale County, was the source of 4 large collections of flame chubs in the 1970s, and flame chubs were common during sampling there in July 2006. This site is protected as part of a small park, although it is unknown if it is explicitly managed for the maintenance of a flame chub population.

Other sites yielding flame chubs were scattered with no easily discernible pattern. The only historic site in Marshall County south of the Tennessee River, Eudy Cave, seems to have a healthy flame chub population and is relatively pristine in spite of being in the middle of a cattle farm. The 1 site of 3 visited in Morgan County that yielded a single flame chub, Dutton Creek, is also surrounded by cattle pasture, with cows having access to the creek both above and below our sampling access.

Surprisingly, flame chubs were found in only 1 of 5 historic sites visited in the upper Paint Rock River system of Jackson County in the Cumberland Plateau physiographic section. Streams in this area show few obvious signs of any abuse, and support populations of other vulnerable fishes such as the blotchside logperch Percina burtoni and palezone shiner Notropis albizonatus. Two historic sites were sampled without success on Larkin Fork in June 2005. One of these sites produced a single flame chub as recently as 2001, and at the other nearby historic site downstream, 8 flame chubs were collected in 1980. This population may have been in decline to the point where it is now difficult to find any flame chubs.

Almost all of the historic sites sampled are in small, isolated streams or springs. These sites are vulnerable to abuse such as that observed at Acuff Spring. Because these sites are isolated, once a small fish such as the flame chub is eliminated, recolonization would not be easy. Only 1 of the 53 sites sampled in this survey is on protected public land, at King Spring in Florence. While sampling fish for another project, flame chubs were found for the first time in Hurricane Creek on the Walls of Jericho tract in the upper Paint Rock River valley in Jackson County, owned by the state of
Alabama. This appears to be the only other flame chub population on protected public lands in Alabama. Any future effort to manage and protect flame chub populations in Alabama will be almost totally reliant on the cooperation of private landowners.

The species seems to have experienced range contraction from a series of small blows resulting in local extirpations. Such pressures are increasing in north Alabama as human population grows along with the expansion of roads and the conversion of rural lands into suburban housing and supporting infrastructure. The flame chub populations in Madison County, especially, are in the immediate path of this expansion as the city of Huntsville attracts more industries and population.

Based on the dramatic reduction of historic sites in Alabama yielding even a single flame chub in this survey, it seems timely to adjust the NatureServe conservation status of the flame chub in Alabama from a rank of S3, Vulnerable, to S2, Imperiled. The S2 rank would reflect an observed steep decline in populations across Alabama over the last $40 \mathrm{yr}$. The global rank of the flame chub is currently G3, Vulnerable. Because the Alabama range is currently about half of the total range of the flame chub, this ranking may be too optimistic, and G2, Imperiled, may be more accurate. A similar survey needs to be done in Tennessee, the other half of the current range of the flame chub. For the same reasons, the IUCN category for the flame chub should be changed back to Rare from Data Deficient.

Acknowledgements. E. Fitz, C. Soto, J. Pinkley, D. Kerstiens, S. Kirkland, L. Marino, A. Adrian, and K. Hammond all helped with field sampling. B. Kuhajda of the University of Alabama Ichthyology Collection provided a spreadsheet of their flame chub holdings. B. Burr of the University of Southern Illinois clarified the status of Kentucky flame chubs. K. Stanton made the sites-visited map and hosted it on his website. The Alabama Department of Conservation of Natural Resources issued Scientific Collecting Permits to the author for the years 2005, 2006, and 2007. Suggestions by 3 anonymous reviewers improved this article.

\section{LITERATURE CITED}

Boschung HT, Mayden RL, Tomelleri J (2004) Fishes of Alabama. Smithsonian Books, Washington, DC

Butler RS (2002) Imperiled fishes of the lower Tennessee Cumberland ecosystem, with emphasis on the non-federally listed fauna. Prepared for the Lower Tennessee Cumberland Ecosystem Team, US Fish and Wildlife Service, Field Office, Asheville, NC

Etnier DA, Starnes WC (1993) The fishes of Tennessee. The University of Tennessee Press, Knoxville, TN

Freeman B, Owers K, Albanese B (2009) In: Protected animals of Georgia. Georgia Department of Natural Resources, Social Circle, GA. Available at www.georgiawildlife.com/ sites/default/files/uploads/wildlife/nongame/pdf/accounts/ 
fishes/hemitremia_flammea.pdf (accessed on 16 September 2009)

Gimenez-Dixon M (1996) Hemitremia flammea. 2006 IUCN Red List of Threatened Species. Available at www. iucnredlist.org/apps/redlist/details/9920/0 (accessed on 12 November 2006)

Hammerson GA, Schweitzer D, Master L, Cordeiro J (2008) Ranking species occurrences - a generic approach. Available at www.natureserve.org/explorer/eorankguide.htm

Kentucky State Nature Preserves Commission (2004) Endangered, threatened, special concern and historical biota of Kentucky. www.naturepreserves.ky.gov/NR/rdonlyres/ 7B21A954-723B-4441-8404-DFEEE4592A20/0/ets00.pdf

Mayden RL, Kuhajda BR (1996) Systematics, taxonomy, and conservation status of the endangered Alabama sturgeon, Scaphirhynchus suttkusi Williams and Clemmer (Actinopterygii, Acipenseridae). Copeia 1996:241-273

McGregor SW, Shepard TE (1995) Investigations of slackwater darter, Etheostoma boschungi, populations, 1992-1994. Circ 184. Geological Survey of Alabama, Tuscaloosa, AL

Mettee MF, O'Neil PE, Pierson JM (1996) Fishes of Alabama and the Mobile Basin. Oxmoor House, Birmingham, AL

Editorial responsibility: Steven Cooke, Ottawa, Ontario, Canada
NatureServe (2009) NatureServe Explorer: an online encyclopedia of life. Version 7.0. NatureServe, Arlington, VA. www. natureserve.org/explorer (accessed on 2 February 2009)

Norman C (1981) Snail darter's status threatened. Science 212:761

Powell JR (2003) Response of fish communities to cropland density and natural environmental setting in the Eastern Highland Rim ecoregion of the lower Tennessee River basin, Alabama and Tennessee, 1999. Water-Resources Investigations Report 02-4268. National Water-Quality Assessment Program, US Geological Survey, Nashville, TN

Scott MC (2006) Winners and losers among stream fishes in relation to land use legacies and urban development in the southeastern US. Biol Conserv 127:301-309

Tomaino A, Cordeiro J, Oliver L, Nichols J (2008) Key for ranking species element occurrences using the generic approach. Available at www.natureserve.org/explorer/ keyforgenericeoranking.pdf

Warren ML Jr, Burr BM, Walsh SJ, Bart HL Jr and others (2000) Diversity, distribution, and conservation status of the native freshwater fishes of the southern United States. Fisheries 25:7-29

Submitted: November 11, 2009; Accepted: April 7, 2010

Proofs received from author(s): June 29, 2010 